\title{
Developing creative-problem-solving-based student worksheets for transformation geometry course
}

\author{
Febriana Kristanti ${ }^{1}$, Chusnal Ainy ${ }^{2}$, Shoffan Shoffa $^{3}$, Siti Khabibah ${ }^{4}$, Siti Maghfirotun Amin ${ }^{5}$ \\ ${ }^{1,2,3}$ Muhammadiyah University of Surabaya, Sutorejo Surabaya, Indonesia \\ ${ }^{4,5}$ Surabaya State University, Ketintang Surabaya, Indonesia
}

\begin{tabular}{l}
\hline A R T I C L E I N F O \\
Original Article \\
Doi: $10.18860 /$ ijtlm.v1i1.5581 \\
\hline
\end{tabular}

Keywords:

Student Worksheet, Creative

Problem Solving,

Transformation Geometry

\begin{abstract}
A B S T R A C T
Students' reasoning ability in understanding the concepts in the Transformation Geometry course is still low. One of the causes is that there are no teaching materials, namely Student Worksheets that provide opportunities for students to be actively involved in creative learning processes; as a result, their reasoning skills are not well crafted. Therefore, it is necessary to develop a Student Worksheet that can strengthen students' creative techniques and reasoning. The purpose of this study was to determine the feasibility of Student Worksheet products in terms of validity, practicality, and effectiveness. This research is an ADDIE development research whose stages comprise analysis, design, development, implementation, and evaluation. The instruments used in this study were validation sheets, student response questionnaires, learning outcomes, and learning implementation observation sheets. The results of this study were Creative Problem Solving (CPS) based Student Worksheet products in Geometry Transformation courses, and Student Worksheet eligibility, declared feasible in terms of (a) Validity; the worksheet validation results were in the very good category (4.36) (b) Practicality; the results of student response questionnaires to Student Worksheets were in a good category (31.16), and (c) effectiveness; the results of the test of student learning outcomes were in a good category $(72 \%)$.
\end{abstract}

(C) 2018 IJTLM. All rights reserved.

*Corresponding author.

E-mail: febriana.pendmat@fkip.um-surabaya.ac.id

How to cite: Kristanti, F., Ainy, C., Shoffa, S., Khabibah, S., \& Amin, S. M. (2018). Developing creative-problem-solving-based student worksheets for transformation geometry course. International Journal on Teaching and Learning Mathematics, 1(1), 13-23.

\section{INTRODUCTION}

Higher education as part of the national education system has an important role in educating the life of the nation and advancing science and technology by paying attention to and applying the values of humanities as well as sustainable Indonesian nationalization and empowerment. One of the roles of universities in improving the education system is to create a learning atmosphere that leads to the formation of the ability to think logically, analytically, systematically, critically, and creatively (Risnawati, 2008). Transformation geometry course is one of the fields of mathematics at the college level that can develop the ability to think logically and effectively and assist students in solving problems in the mathematical fields (Guven, 2012; Hourigan, \& Leavy, 2017; Sherard, 1981; Zambak \& Tyminski 2017).

Transformation geometry is an extension of geometrical concepts that can develop creative 
activities involving imagination, intuition, and discovery through the development of thinking, curiosity, making predictions and guesses, and experimenting (Nagy-Kondor, 2010). According to De Villiers \& Njisane (1987), many students experience difficulties in learning geometry. Those in higher education also experience this. Students have not had the opportunity to do meaningful activities, such as discovering their concepts and principles of mathematics, exploring concepts, and applying them, for example in the concept of transformation geometry, that is, interpreting points, lines, and fields both analytically and analytically. One of the contributing factors is that the students' ability to manipulate geometry objects physically and mentally in learning activities is still low. Also, the external factors involved are that there is no learning source that can play the maximum role in building patterns of interaction between lecturers and students and between students and other students so as to develop their ability to think about and applying the concepts in order to create effective lecture activities (Suryawati \& Osman, 2017).

Lecture activities become effective if the learning outcomes achieve optimal results. This can be realized if there is an effort to innovate learning through the implementation of strategies and methods to improve learning resources that actively involve students. Learning resources are a system in the form of a collection of materials that are made intentionally so that students are facilitated individually (Viberg \& Grönlund 2017). One of the learning resources created for learning purposes is printed teaching materials in the form of Student Worksheets. Student Worksheets are one of the right learning alternatives for students because they help to add information about the learned concepts systematically (Chi, Kang, \& Yaghmourian, 2017; Fetherstonhaugh \& Treagust, 1992; Hmelo-Silver, 2004; Suyitno, 1997). Student Worksheets are one of the means to facilitate learning activities so that effective interactions are formed between students and lecturers, and they can increase student effort in improving their learning achievement. Therefore, since the Student Worksheets are expected to guide students to find the concept of learning through everyday problem solving, they need to be designed so well that they contain structured material, summaries, and tasks related to daily life.

However, often students are faced with worksheet whose design cannot accommodate their activities in the learning process. Worksheets received by students tend to only contain definitions of a concept, sample questions, and some practice questions. In this case, the worksheets have not facilitated students to construct their knowledge nor encourage them to develop their thinking skills. A worksheet design is often far from solving problems in everyday life, and monotonous, lacking the steps that can facilitate the implementation of learning.

Several studies that are relevant to this study include research on the development of Realistic Mathematics-based worksheets that are designed to apply learning concepts to real conditions through the Realistic Mathematics approach to develop problem-solving skills (Zulyadaini, 2017). Development of the Cemil, Serdar, and Zea (2017) produces worksheets based on the theory of Multiple Intelligences that facilitate students with visual-spatial intelligence and verbal-linguistic intelligence to express themselves clearly in the subjects. The results of Joko's research (2016) produced worksheets that use GeoGebra with learning based on problems that influence on mathematical discovery abilities to build the skills in constructing geometric objects both manually and non-technologically.

Based on this, this research is about the development of the Creative Problem Solving (CPS) based Student Worksheet in Transformation Geometry course. CPS comes from the words creative, problem, and solving. Creative means having many new and unique ideas in finding solutions as well as value and relevance. The Problem means a situation that provides 
interrelated challenges and opportunities while solving means planning a way to answer from a problem (Mitchell, Kowalik, \& Thomas, 1999). The CPS learning model is an extension of the Problem-Solving lesson. CPS-based Student Worksheets are worksheets that represent systematic procedures in identifying challenges, creating ideas, and applying innovative solutions. Through the practice and application of CPS designed sustainably on student worksheets, students will be able to strengthen their creative techniques and adaptive reasoning. During the learning process by using CPS-based Student Worksheets, students have a wide opportunity to solve problems in the worksheet with the aim that they can be active in building their knowledge through direct experience so that Geometry Transformation learning is well achieved. The steps on a CPS-based Student Worksheets are based on the Osborn-Parnes problem-solving model, namely (1) Mess-finding (finding a problem perceived as a distractor; the first step is an attempt to identify a situation that feels disturbing; (2) Fact-finding (finding facts); in this step the students list all known facts and relate them to the situation to find unknown but essential information on the situation being identified and searched for. The second step involves divergent and convergent ways of thinking. A divergent thinking process occurs when students reveal things that are considered facts, while convergent thinking is used when considering and deciding what is the most important fact, (3) Problem-finding; in this step students attempt to identify all possible problem statements and then choose what is the most important or the source of the problem. This step involves divergent thinking when students record everything, they feel consider a problem. When students consider and decide that a statement is a problem, they have used the process of convergent thinking; (4) Idea-finding; the fourth step is that students try to find some ideas and ideas that are possible to solve the problem. In this step, students only use the divergent thinking process, which is trying to guess and register ideas that might be a problem solving; (5) Solution-funding (finding solutions); in this step students complete solutions, ideas and ideas that have been obtained at the idea-finding stage to find the most appropriate ideas in solving problems systematically. In this step, the student thinking process is both divergent and convergent. Students think divergently when they suspect what is the most appropriate idea to be a solution, while convergent thinking occurs when they provide analytical justification for the allegations previously given; (6) Acceptancefinding; in this stage, students try to gain input of the solution to the problem, develop action plans, and implement solutions. The input is in the form of a concept or solution that is received by using divergent and convergent thinking processes to decide again that the solution they obtain is right.

The development of student worksheets to assist students in understanding the concept of Geometry Transformation requires an instructional design that is used for reference. This study uses the instructional design model of ADDIE development (analysis, design, development, implementation, and evaluation). The stages of the ADDIE development model, according to Sugiyono (2017), are: (1) Analysis; this stage is related to the analysis of the work situation and the environment so as to decide what products need to be developed; (2) Design; this stage is an activity of designing products according to what is needed; (3) Development; this stage is an activity of making and testing products; (4) Implementation; this stage is an activity to use the product; (5) Evaluation; this stage is an activity to assess whether every step of the activities and products that have been made are in accordance with the specifications or not.

The development of a student worksheet has good quality if it meets the three criteria proposed by Tjeerd \& Nieveen (2007), namely validity, practicality, and effectiveness. The validity criteria obtained from the student worksheet are developed based on state-of-the-art 
(scientific) knowledge, and the various components in the student worksheet that are being developed are related to one another. Practicality criteria are seen from whether the student worksheets that are being developed can be easily used by students in learning. The effectiveness criteria can be seen from whether using a developed student worksheet can produce the desired results, namely the achievement of a learning goal.

Based on the background, this study aims to: (1) develop Student CPS-based worksheets on Transformation Geometry courses for mathematics education students; (2) figure out the feasibility of CPS-based student worksheets in terms of validity, practicality, and effectiveness. This research is expected to provide some benefits including: (1) For students, this developed worksheets can guide them in finding their own geometry sub-material concepts of translation, reflection, rotation, and dilation; (2) for lecturers, this worksheets can be used by lecturers as teaching materials in the learning process, and can also be used as a discourse to improve the creativity of lecturers in developing worksheets or other teaching materials; (3) for other researchers the developed worksheets can add insight into the development of Mathematical worksheets and then can be used as a reference for developing worksheets for other subjects.

\section{METHOD}

This research is research and development $(\mathrm{R} \& \mathrm{D})$ research. The product developed in this study is the CPS-based student worksheets for the Geometry Transformation course for mathematics education students by referring to the ADDIE development model which consists of five stages, namely analysis, design, development, implementation, and evaluation (Alcid, Bandril, De Guzman, \& Lopez, 2017).

The data used in this study is quantitative data which will then be converted into qualitative data through data analysis. The quantitative data was obtained from (1) the results of the student worksheet validation by the validator; (2) results of student response questionnaires; (3) the test results of student learning outcomes. In collecting the three data, several research instruments were used, namely: (1) Validation sheets, needed to determine the feasibility of the student worksheets in terms of validity aspects; (2) Questionnaire for student responses, needed to determine the feasibility of the student worksheets in terms of practicality; (3) Test of student learning outcomes, needed to determine the feasibility of student worksheets in terms of effectiveness aspects; and (4) Observation sheet, as an additional instrument needed only to find out the implementation of learning using developed student worksheets.

Research on the development of CPS-based student worksheets in transformation Geometry courses is carried out from March to May 2018. Subjects in this study consisted of two types, namely the pilot test subjects and limited trial subjects at the development stage, and the actual test subjects at the implementation stage. The peer test subjects were 5 fellow researchers and limited test subjects were 20 mathematics education students in the 2014/2015 academic year, while the actual test subjects were 25 mathematics education students in the 2015/2016 academic year.

The analysis phase consisted of 3 activities, namely: (a) needs analysis, at this stage teaching materials that need to be developed were determined; (b) Analysis of the curriculum, at this stage the Competency Standards and Basic Competencies were studied by students in Geometry Transformation materials; (c) Analysis of student characteristics; at this stage a study of the stages of student cognitive development through class observation was carried out.

The design phase consisted of 2 activities, namely the drafting of the student worksheet (draft 1) and the design of the student worksheet feasibility instrument. Worksheets were 
designed about the structure of the student worksheet which consists of 6 components, namely the title, study instructions, competencies achieved, supporting information, tasks and procedure, and assessment. While the student worksheet feasibility instrument designed included a student worksheet validation sheet, student response questionnaire, and student learning outcomes test.

In the development phase, the student worksheets were developed by the design at the design stage. The developed student worksheets consisted of draft 1, draft 2, and draft 3 . Before the experts assessed the student worksheets, the worksheets (draft 1) were first tested for 5 fellow researchers to evaluate their readability. Then, the student worksheets (draft 2) were validated by the experts (validators) using the student worksheet validation sheet. The results of the student worksheet validation were used as a reference to determine the feasibility of the student worksheet in terms of validity and in deciding whether the student worksheet was worthy of a limited trial of small groups.

The implementation phase was tested in the actual class. The purpose of this phase was to determine the feasibility of the student worksheet in terms of practicality and effectiveness by filling in the student response questionnaire and student learning outcomes test.

In the evaluation stage, an analysis of the results of the questionnaire responses and student learning outcomes tests were carried out. The evaluation phase aimed to find out whether the student worksheet being developed still needed to be improved based on errors that occurred during learning, including suggestions and comments from student response questionnaires as well as from Transformation Geometry lecturers. Data analysis techniques in the development of student worksheets are said to have good quality if they meet the three criteria stated by Tjeerd \& Nieveen (2007), namely validity (practicality), practicality, effectiveness (effectiveness), and learning implementation.

Validity Analysis Instrument used for validity analysis is a validation sheet filled by the validator. The validation results obtained were then analyzed by the following steps. The first step is calculating the average total score of each aspect that includes instructions, completeness of contents, procedures, and questions. Then the average total score was converted into qualitative data based on conversion guidelines. The ideal maximum score on the validation sheet is 5 , while the ideal minimum score is 1 . The student worksheets are declared eligible in terms of validity if the results of the validation analysis are in the good or very good category.

The instrument used for practicality analysis was the student response questionnaire. The results of the questionnaire were then analyzed by the following steps. It begins by calculating the average total score of 25 students (respondents). Then the average total score is converted into qualitative data based on conversion guidelines. The maximum score is the highest score obtained from the student response questionnaire, while the minimum score is the lowest score obtained from the student response questionnaire results. The worksheet is declared eligible in terms of practicality if the results of the student response questionnaire analysis are in the good or very good category.

The instrument used for effectiveness analysis was a test of learning outcomes. The test results obtained were then analyzed by the following steps. It is started by calculating the scores obtained by students using guidelines for scoring test results. Then, calculating the number of students who complete if they are in the category of more than adequate, good, and very good by using the assessment. The student worksheets are declared feasible in terms of the effectiveness aspect if the percentage of classical completeness is in the good or very good category. 
The instrument used for the analysis of the implementation of learning using student worksheets is an observation sheet. The results of the observations obtained were then analyzed by the following steps: (1) Calculating the score of each item statement, with score 1 for the option "Yes" and score 0 for the choice "No". (2) Calculating the percentage of learning implementation at the first, second, third, and fourth meetings using the formula. (3) Furthermore, the percentage of the learning implementation was converted into qualitative data. Learning to use student worksheets was considered to have been implemented if the percentage of learning implementation is in the good or very good category.

\section{RESULTS AND DISCUSSION}

Student worksheets development began with a theoretical review process, relevant research results, followed by observations to obtain information about teaching materials and curriculum used by universities and the characteristics of students. The information obtained was used to design the student worksheets (draft 1) and the design of the student worksheet feasibility assessment instrument was prepared at the design stage. Then the development of student worksheets (draft 1) was carried out to produce student worksheets (draft 3) that were declared feasible based on the validity aspect according to the validation results in Table 1.

Table 1. Student worksheets validation results

\begin{tabular}{ccc}
\hline No. & Validator & $\begin{array}{c}\text { Total score } \\
\text { obtained }\end{array}$ \\
\hline 1 & Media experts & 96 \\
2 & Education experts & 94 \\
3 & Geometry experts & 98 \\
& Total score & 288 \\
& Student worksheets & 4,36 \\
& validation score & \\
& average & \\
\hline
\end{tabular}

The validator input for improvement was that the student worksheets had to bring up a systematic process in the students so they can find creative ideas in solving problems. The results of the revised student worksheets adapted the steps of the CPS learning model according to Mitchell, Kowalik, \& Thomas (1999). The revised results (draft 3) were related to the problem-solving process in Table 2. 
International Journal on Teaching and Learning Mathematics

2018, Vol. 1, No. 1, pp. 13-23

P-ISSN: 2621-2188, E-ISSN: 2621-2196

Table 2. Revised student worksheets

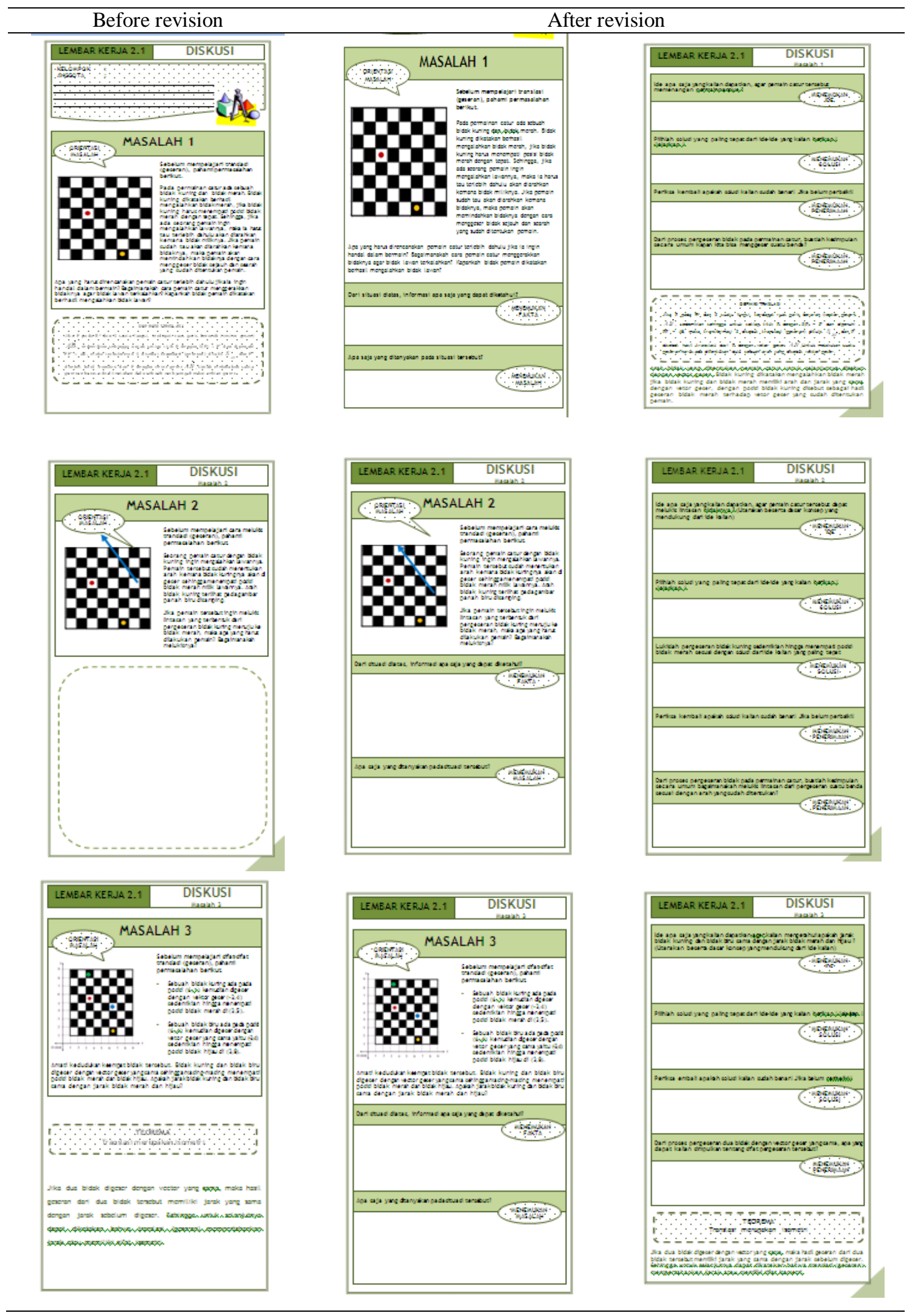


The results of the student response questionnaire analysis in Table 3 were then applied to the guideline formula for conversion of the average total score of questionnaires in Table 1 to obtain the categories in Table 4.

Table 3. The results of the student response questionnaire analysis

\begin{tabular}{ccccccc}
\hline $\begin{array}{c}\text { Number of } \\
\text { students }\end{array}$ & $\begin{array}{c}\text { Total } \\
\text { score }\end{array}$ & $\begin{array}{c}\text { Average total } \\
\text { score }\end{array}$ & $\begin{array}{c}\text { Max. } \\
\text { score }\end{array}$ & $\begin{array}{c}\text { Min. } \\
\text { score }\end{array}$ & $\begin{array}{c}\text { Mean } \\
\text { ideal } \\
\left(\mathrm{M}_{\mathrm{i}}\right)\end{array}$ & $\begin{array}{c}\text { Standard } \\
\text { deviation } \\
\left(\mathrm{Sb}_{\mathrm{i}}\right)\end{array}$ \\
\hline 25 & 779 & 31.16 & 24 & 8 & 8 & 2.67 \\
\hline
\end{tabular}

Table 4. Category of Average of total questionnaire scores

\begin{tabular}{cc}
\hline Interval & Category \\
$\bar{x}>3.21$ & Very good \\
$2.40<\bar{x} \leq 3.21$ & Good \\
$1.59<\bar{x} \leq 2.40$ & Enough \\
$0.79<\bar{x} \leq 1.59$ & Inadequate \\
$\bar{x} \leq 0.79$ & Very inadequate \\
\hline
\end{tabular}

Student worksheets that have been declared eligible based on the validity aspect were then implemented or tested on students in the 2015/2016 academic year of the mathematics education program of the Muhammadiyah University of Surabaya. At the time of the implementation of the student worksheet, observations were also carried out by two observers to find out how to implement learning in the classroom using the student worksheet for 6 meetings. At the 7th meeting, a test of student learning outcomes was carried out and the student response questionnaire was distributed. The results of the tests and the results of the questionnaire were used as data to determine the feasibility of the student worksheets based on effectiveness and practicality aspects.

After the implementation phase was carried out the evaluation phase started. At this stage, the researcher analyzed the data obtained from the results of tests and questionnaires. The student worksheets are declared eligible in terms of practicality and effectiveness if the results of the questionnaire and student test results are in the good or very good category.

Based on the results of the analysis, the average total score of the student response questionnaire was 31.16 or in the good category. Thus, the student worksheets were declared eligible in terms of practicality.

Table 5. Results of analysis of student learning outcomes tests

\begin{tabular}{ccc}
\hline Description & Number of students & $\begin{array}{c}\text { Percentage } \\
(\%)\end{array}$ \\
\hline Complete & 18 & 72 \\
Incomplete & 7 & 28 \\
\hline
\end{tabular}

Based on Table 5, the results of the analysis of student learning outcomes with the percentage of completeness of $72 \%$ are in a good category, and as such the student worksheets 
are declared feasible in terms of effectiveness aspects.

Based on the description of the research results above which stated that student worksheets are feasible in terms of practicality, it can be said that student worksheets in CPS-based Geometry Transformation courses are practically used by students so that the learning process can run well and creatively, in accordance with the theory proposed by Bruner that the learning process will run well and creatively if the lecturer provides opportunities for students to find their own rules through concepts, theories, definitions, and so on (Tung, 2015). Because of its practicality, the CPS-based student worksheets can guide students to find their concepts about translation, rotation, reflection, and dilatation in Transformation Geometry courses.

Besides being practically used by students, CPS-based worksheets are also effectively used in learning because they enable students to construct their knowledge about the concepts of translation, rotation, reflection, and dilation. This is in line with the opinion of Bruner in Suyono \& Hariyanto (2011) that lecturers must guide their students so that they can build their knowledge base rather than teaching them through rote memorization.

The effectiveness of CPS-based student worksheets is proven based on test results which show that as many as 17 out of 25 students were able to fully understand the concepts of translation, rotation, reflection, and dilation in Geometry Transformation courses in the student worksheets. This is in line with the explanation put forward by Trianto (2010) that the student worksheets contain a set of fundamental activities that must be carried out by students to maximize understanding in the effort to establish basic abilities according to indicators of achievement of learning outcomes that must be met.

\section{CONCLUSION}

This study found the feasibility of Student Worksheet for translation, rotation, reflection, and dilation material in CPS-based Transformation Geometry courses in terms of validity, practicality, and effectiveness which could be seen from: (a) validation results are in good category so that Student Worksheet are declared eligible in terms of validity; (b) the results of student response questionnaires are in good category so that the Student Worksheet is declared eligible in terms of practicality; and (c) the results of the student learning outcomes test are in good category so that the Student Worksheet is declared eligible in terms of effectiveness aspects.

\section{ACKNOWLEDGMENTS}

I would like to Thanks also to the Ministry of Research, Technology and Higher Education (PKPT) which has provided the opportunity through the Inter-Higher Education Cooperation Research grant program to work in the field of educational research.

\section{REFERENCES}

Alcid, A. S., Bandril, L. B. P., De Guzman, A. E., \& Lopez, L. J. C. (2017). Analysis, design, development, implementation, and evaluation of a serious game designed to inform users on environmental issues. International Journal of Computing Sciences Research, 1(1), 11-23.

Cemil, I., Serdar, E., \& Zea, G. (2017). The effect of mathematical worksheets based on multiple intelligences theory on the academic achievement of the students in the 4th grade primary school. Universal Journal of Educational, 5(8), 1372-1377. 
Chi, M. T., Kang, S., \& Yaghmourian, D. L. (2017). Why students learn more from dialoguethan monologue-videos: Analyses of peer interactions. Journal of the Learning Sciences, 26(1), 10-50.

De Villiers, M. D., \& Njisane, R. M. (1987). The development of geometric thinking among black high school pupils in Kwazulu (Republic of South Africa). In Proceedings of the 11th Conference of the International Group for the Psychology of Mathematics Education (Vol. 3, pp. 117-123). Montreal: PME.

Guven, B. (2012). Using dynamic geometry software to improve eight grade students' understanding of transformation geometry. Australasian Journal of Educational Technology, 28(2), 364-382.

Fetherstonhaugh, T., \& Treagust, D. F. (1992). Students' understanding of light and its properties: Teaching to engender conceptual change. Science Education, 76(6), 653-672.

Hourigan, M., \& Leavy, A. M. (2017). Preservice primary teachers' geometric thinking: Is pretertiary mathematics education building sufficiently strong foundations?. The Teacher Educator, 52(4), 346-364.

Hmelo-Silver, C. E. (2004). Problem-based learning: What and how do students learn?. Educational psychology review, 16(3), 235-266.

Joko, S. (2016). The development of students worksheet using geogebra assisted problem-based learning and its effect on ability of mathematical discovery of junior high students. In Proceeding of 3rd International Conference on Research, Implementation and Education of Mathematics and Science Yogyakarta (p. 385). Khairun: Department of Mathematics and Science Education, University of Khairun.

Tung, K. Y. (2015). Pembelajaran dan perkembangan belajar (1st ed.). Jakarta: PT. Indeks.

Lestari, I. (2013). Pengembangan bahan ajar berbasis kompetensi sesuai dengan kurikulum tingkat satuan pendidikan. Padang: Akademia.

Mitchell, E., Kowalik, \& Thomas, F. (1999). Creative problem solving (3rd ed.). London: Genigraphics Inc.

Nagy-Kondor, R. (2010). Spatial ability, descrptive geometry and DGS. Journal of Annales Mathematics Informatic, 37(3), 199-210.

Risnawati. (2008). Strategi pembelajaran matematika. Pekanbaru: Suska Press.

Sherard, W. H. (1981). "Why is geometry a basic skill?" The Mathematics Teacher, 19-21.

Sugiyono. (2017). Metode penelitian \& pengembangan "research and development." (S. Y. Suryandari, Ed.). Bandung: Alfabeta.

Suryawati, E., \& Osman, K. (2017). Contextual learning: Innovative approach towards the development of students' scientific attitude and natural science performance. Eurasia Journal of Mathematics, Science and Technology Education, 14(1), 61-76.

Suyitno, A. (1997). Dasar dan proses pembelajaran matematika I. Semarang: FMIPA UNNES.

Suyono, \& Hariyanto. (2011). Belajar dan pembelajaran (teori dan konsep dasar). Bandung: Remaja Rosdakarya.

Tjeerd, \& Nieveen, N. (Eds.). (2007). An introduction to educational design research. Netherlands: SLO Netherland Institute for Curriculum Development.

Trianto. (2010). Mendesain model pembelajaran inovatif-progresif (konsep, landasan, implementasinya pada kurikulum tingkat satuan pendidikan). Jakarta: Prenada Media Group. 
International Journal on Teaching and Learning Mathematics

2018, Vol. 1, No. 1, pp. 13-23

P-ISSN: 2621-2188, E-ISSN: 2621-2196

Viberg, O., \& Grönlund, Å. (2017). Understanding students' learning practices: Challenges for design and integration of mobile technology into distance education. Learning, Media and Technology, 42(3), 357-377.

Widoyoko, S., \& Eko, P. (2015). Evaluasi program pembelajaran panduan praktis bagi pendidik dan calon pendidik. Yogyakarta: Pustaka.

Zambak, V. S., \& Tyminski, A. M. (2017). A case study on specialised content knowledge development with dynamic geometry software: The analysis of influential factors and technology beliefs of three pre-service middle grades mathematics teachers. Mathematics Teacher Education and Development, 19(1), 82-106.

Zulyadaini. (2017). Development of student worksheets based realistic mathematics education (RME). International Journal of Engineering Research and Development, 13(2), 1-14. 